\begin{tabular}{ccccc}
\hline $\begin{array}{c}\text { Duration of } \\
\text { diabetes } \\
\text { at entry } \\
\text { (years) }\end{array}$ & $\begin{array}{c}\text { Excretion rate } \\
\text { at entry } \\
(\mathrm{mg} / 24 \mathrm{~h})\end{array}$ & $\begin{array}{c}\text { Estimated annual rate } \\
\text { of increase }(\%)\end{array}$ & $\begin{array}{c}\text { Estimated excretion } \\
\text { rate at } \\
\text { follow up } \\
(\mathrm{mg} / 24 \mathrm{~h})\end{array}$ & $\begin{array}{c}\text { Estimated time } \\
\text { from entry to overt } \\
\text { nephropathy } \\
\text { (years) }\end{array}$ \\
\hline 16 & 75 & $12 \cdot 6$ & 246 & 12 \\
26 & 75 & $7 \cdot 8$ & 158 & 20 \\
37 & 75 & $5 \cdot 5$ & 128 & 26 \\
\hline
\end{tabular}

vascular disease, although the data could be retrieved from the paper. It is clear that microalbuminuria in patients with longstanding insulin dependent diabetes mellitus confers an increased risk of nephropathy. The risk is, however, only one third of the risk reported in patients with a shorter duration of disease. ${ }^{1}$

As outlined above, arterial hypertension was associated with the progression from microalbuminuria to macroalbuminuria. The blood pressures in our study, however, did not differ significantly from those reported in the two previous studies. ${ }^{2}$ Although high blood pressure seems crucial for the progression to overt nephropathy in patients with insulin dependent diabetes mellitus, it is unlikely to explain the difference between the current and previous studies.

We agree with Viberti and Friedman that if patients with longstanding insulin dependent diabetes mellitus are to be excluded from trials aiming at preventing the progression from microalbuminuria to macroalbuminuria it may be most rewarding to exclude patients with disease of more than 20 years' duration. Finally, given the paucity of data, these guidelines should be regarded as tentative until confirmed by a larger independent study.

LEIF GROOP

CAROL FORSBLOM PER-HENRIK GROOP Of the three initially macroalbuminuric patients who regressed to microalbuminuria, one had hypertension at the initial screening and another developed hypertension during follow up. In accordance with treatment policy at that time, both these patients were treated with angiotensin converting enzyme inhibitors.

Thus the data do not support the view that the lower rate of progression in our patients was due to more efficient antihypertensive treatment. In contrast, they indicate that progression to macroalbuminuria in these patients was associated with failure to normalise the blood pressure.

In reply to Gian Carlo Viberti and Rogerio Friedman, our paper dealt with microalbuminuria as a risk factor for progression to overt nephropathy in patients with longstanding insulin dependent diabetes mellitus compared with patients with disease of shorter duration. Unfortunately, we had to extract the latter data from published reports. ${ }^{12}$ The difference between our and the quoted studies was, however, obvious- $28 \%$ v $88 \%$ or $86 \%$-suggesting that the patients with longstanding disease are less susceptible to progression to overt nephropathy. We did not particularly address the issue of whether microalbuminuria in general is a risk factor for both diabetic nephropathy and cardio-

Fourth Department of Medicine, AGNETA EKSTRAND

Helsinki University Hospital

SF-00170 Helsinki,

Finland

1 Viberti GC, Hill RD, Jarrett RJ, Argyropoulos A, Mahmud U, Keen $\mathrm{H}$. Microalbuminuria as a predictor of clinical nephropathy in insulin dependent diabetes mellitus. Lancet 1982;i: pathy in
$1+30-2$.

2 Mogensen CE, Christensen CK. Predicting diabetic nephropathy in insulin-dependent patients. N Engl F Med 1984;311:89-93.

\title{
Managing depression in general practice
}

EDIToR,-As a former general practitioner I enjoyed E S Paykel and R G Priest's comprehensive report on the recognition and management of depression in general practice. ${ }^{1}$ But to describe the traditional tricyclic antidepressants as cheap on the basis of drug costs is inappropriate as it disregards expensive problems associated with their use.

Johnson found that $68 \%$ of patients in general

Mean blood pressure ( $95 \%$ confidence interval) and prevalence of antihypertensive treatment at initial screening and at follow up in insulin dependent diabetic patients with normoalbuminuria, microalbuminuria, and macroalbuminuria

basis of repeated measurements may thus be more relevant. When progression of microalbuminuria is being studied the rate of increase may prove to be a more sensitive outcome variable than the conventional semiquantitative classification as it can even be used as a continuous outcome variable in the analysis.

Institute of Preventive Medicine,

KNUT BORCH-JOHNSEN

Kommunehospitalet,

DK-1399 Copenhagen,

Denmark

1 Forsblom CM, Groop P-H, Ekstrand A, Groop L. Predictiv value of microalbuminuria in patients with insulin-dependen diabetes of long duration. $B M 7$ 1992;305:1051-3. (31 October.)

2 Christensen CK. The pre-proteinuric phase of diabetic nephropathy. Dan Med Bull 1991;38:145-59.

3 Siegel JE, Krolewski AS, Warram JH, Weinstein MC. Costeffectiveness of screening and early treatment of nephropathy in patients with insulin dependent diabetes mellitus. Foumal of the American Society of Nephropathy 1992;3:S111-9.

4 Viberti GC, Jarrett RJ Amephropathy 1992;3:S111-9. a predictor of clinical nephropathy in insulin-dependent a predictor of clinical nephropathy
diabetes mellitus. Lancet 1982;i:1430-2

5 Mogensen CE, Christensen CK. Predicting diabetic nephropathy in insulin-dependent diabetic patients. $N$ Engl $\mathcal{F}$ Med 1984 311:89-93.

6 Mathiesen ER, Oxenbøll B, Johansen K, Svendes PA, Decker $T$. Incipient nephropathy in type 1 (insulin-dependent) diabetes. Diabetologia 1984;26:406-10.

\begin{tabular}{|c|c|c|c|c|c|c|c|}
\hline \multirow[b]{2}{*}{ Albuminuria at follow up } & \multicolumn{3}{|c|}{ Initial screening } & \multicolumn{4}{|c|}{ At follow up } \\
\hline & $\begin{array}{c}\text { Systolic blood } \\
\text { pressure } \\
(\mathrm{mm} \mathrm{Hg})\end{array}$ & $\begin{array}{c}\text { Diastolic } \\
\text { blood } \\
\text { pressure } \\
(\mathrm{mm} \mathrm{Hg})\end{array}$ & $\begin{array}{c}\text { No } \\
\text { receiving } \\
\text { antihyper- } \\
\text { tensive } \\
\text { treatment }\end{array}$ & $\begin{array}{l}\text { Systolic blood } \\
\text { pressure } \\
(\mathrm{mm} \mathrm{Hg})\end{array}$ & $\begin{array}{l}\text { Diastolic } \\
\text { blood } \\
\text { pressure } \\
(\mathrm{mm} \mathrm{Hg})\end{array}$ & $\begin{array}{l}\text { No receiving } \\
\text { antihypertensive } \\
\text { treatment }\end{array}$ & $\begin{array}{l}\text { No } \\
\text { receiving } \\
\text { ACE } \\
\text { inhibitor }\end{array}$ \\
\hline \multicolumn{8}{|c|}{ Normoalbuminuria initially $(n=26)$} \\
\hline Normoalbuminuria $(n=20)$ & $\begin{array}{c}128 \\
\text { (120 to } 136)\end{array}$ & $\begin{array}{c}78 \\
\text { (74 to } 82)\end{array}$ & 0 & $\begin{array}{c}132 \\
(126 \text { to } 138)\end{array}$ & $\begin{array}{c}81 \\
(76 \text { to } 86)\end{array}$ & 2 & 1 \\
\hline Microalbuminuria $(n=4)$ & $\begin{array}{c}126 \\
(104 \text { to } 148)\end{array}$ & $\begin{array}{c}79 \\
(70 \text { to } 89)\end{array}$ & 0 & $\begin{array}{c}127 \\
(95 \text { to } 159)\end{array}$ & $\begin{array}{c}82 \\
(70 \text { to } 94)\end{array}$ & 1 & 1 \\
\hline Macroalbuminuria $(n=2)$ & 120 & $\begin{array}{c}83 \\
(47 \text { to } 119)\end{array}$ & 0 & $\begin{array}{c}135 \\
\text { (63 to } 207)\end{array}$ & 84 & 1 & 1 \\
\hline \multicolumn{8}{|c|}{ Microalbuminuria initially $(n=18)$} \\
\hline Microalbuminuria $(n=13)$ & $\begin{array}{c}135 \\
(120 \text { to } 150)\end{array}$ & & 3 & $\begin{array}{c}137 \\
(125 \text { to } 149)\end{array}$ & $\begin{array}{c}79 \\
\text { (70 to } 88)\end{array}$ & 4 & 0 \\
\hline Macroalbuminuria $(n=5)$ & $\begin{array}{c}150 \\
(116 \text { to } 184)\end{array}$ & $\begin{array}{c}95 \\
\text { (88 to } 102)\end{array}$ & 3 & $\begin{array}{c}162 \\
(137 \text { to } 187)\end{array}$ & $\begin{array}{c}90 \\
(78 \text { to } 102)\end{array}$ & 5 & 2 \\
\hline \multicolumn{8}{|c|}{ Macroalbuminuria initially $(n=22)$} \\
\hline Microalbuminuria $(n=3)$ & $\begin{array}{c}146 \\
(109 \text { to } 183)\end{array}$ & $\begin{array}{c}94 \\
\text { (62 to } 126)\end{array}$ & 1 & $\begin{array}{c}135 \\
\text { (78 to } 192)\end{array}$ & $\begin{array}{c}81 \\
\text { (59 to 103) }\end{array}$ & 2 & 2 \\
\hline Macroalbuminuria $(n=12)$ & $\begin{array}{c}147 \\
(135 \text { to } 159)\end{array}$ & $\begin{array}{c}93 \\
(85 \text { to } 101)\end{array}$ & 9 & $\begin{array}{c}136 \\
(118 \text { to } 154)\end{array}$ & $\begin{array}{c}83 \\
\text { (79 to } 87)\end{array}$ & 12 & 3 \\
\hline $\begin{array}{l}\text { End stage renal failure } \\
\qquad(\mathrm{n}=7)\end{array}$ & $\begin{array}{c}147 \\
(127 \text { to } 167)\end{array}$ & $\begin{array}{c}87 \\
(82 \text { to } 93)\end{array}$ & 6 & $\begin{array}{c}145 \\
(133 \text { to } 157)\end{array}$ & $\begin{array}{c}81 \\
(61 \text { to } 101)\end{array}$ & 7 & 2 \\
\hline
\end{tabular}

$\mathrm{ACE}=$ Angiotensin converting enzyme. 
practice who were treated with tricyclic antidepressants were non-compliant after four weeks.' In another study psychiatric outpatients taking traditional tricyclic antidepressants showed compliance of only $46 \%$, compared with $71 \%$ for patients given newer antidepressants. ${ }^{3}$ Even when compliance is adequate, concern over side effects (for example, sedation, orthostatic hypotension, anticholinergic effects, long term weight gain) means that patients receive inadequate doses $^{4}$ and are treated for an insufficient time.

The cardiovascular toxicity of tricyclic antidepressants results in some 300 deaths from overdose every year. ${ }^{5}$ This must be a primary consideration-not just in economic terms. Impairment of psychomotor function by tricyclic antidepressants may increase liability to accidents. In a review of motorway accidents drowsiness was the direct cause of $27 \%$ of accidents and $83 \%$ of the deaths. ${ }^{6}$ The relation between falls in elderly people, involving femoral fractures, and sedative drugs is well established.

The newer antidepressants, such as the specific serotonin reuptake inhibitors, cost more but increase the likelihood of compliance at an adequate dose for a sufficient time and without serious toxicity. They appreciably improve the risk:benefit ratio for antidepressant treatment with drugs. Specific serotonin reuptake inhibitors have been shown to be as effective as tricyclic antidepressants in treating depression. They can be started at an effective dosage (in a single tablet daily), unlike tricyclic antidepressants, which must be titrated from an initial low dose to an effective dose. They are unlikely to sedate. ${ }^{8}$ They do not exhibit the typical side effects of tricyclic antidepressants, and they have a greatly reduced toxicity in overdose. Side effects are usually predictable and dose related, principally in the gastrointestinal and central nervous systems, and are generally acute and mild and ameliorate with continued treatment. ${ }^{9}$

The main component of the cost of treatment is the cost of failure of the treatment. The largest contributor to the direct costs of depression is not the cost of drugs but the cost of inpatient and outpatient care. $^{10}$ When viewed in the wider context of cost-benefit the traditional tricyclic antidepressants may deserve the label of an expensive therapeutic option and the newer drugs may be more cost effective.

Medical Department,

ROGER LANE

Pfizer,

Sandwich,

Kent CT13 9NJ

1 Paykel ES, Priest RG. Recognition and management of depression in general practice: consensus statement. BMF 1992;305: sion in general practice: consen

2 Johnson DAW. Depression: treatment compliance in general practice. Acta Psychiatr Scand 1981;63:447-53.

3 Johnson DAW. Non compliance with antidepressant therapyan underestimated problem. International Medicine 1986; 11(suppl): 14-7.

4 Thompson C, Thompson CM. The prescribing of antidepressants in general practice. II. A placebo controlled trial of low dose dothiepin. Human Psychopharmacology 1989;4:A1-204.

5 Henry JA, Antao CA. Suicide and fatal antidepressant poisoning. European fournal of Medicine 1992;1:343-8.

6 Parsons M. Fits and other causes of loss of consciousness while driving. Qf Med 1986;227:295-303.

7 Macdonald JB. The role of drugs in falls in the elderly. Clin Geriatr Med 1985;1:621-36.

8 Kerr JS, Sherwood N, Hindmarch I. The comparative psychopharmacology of 5-HT reuptake inhibitors. Human Psychopharmacology 1991,6:313-7.

9 Doogan DP, Caillard V. Sertraline in the prevention of depression. Br f Psychiatry 1992;160:21 7-22.

10 Stoudemire A, Frank R, Hedemark N, Kamlet M, Blazer D. The economic burden of depression. Gen Hosp Psychiatry 1986;8:387-94

EDITOR,-The consensus statement on the recognition and management of depression in general practice provides useful guidelines,' but one of the recommendations gives cause for concern.

Antidepressants are recommended for long term prophylaxis against unipolar affective disorder despite the authors' admission that neither the dosage nor the duration of such treatment has been established. Indeed, no antidepressant apart from sertraline is licensed in the United Kingdom for the prevention of recurrence in depression, which means that practitioners are expected to take upon themselves the liability for these drugs' unlicensed use. ${ }^{2}$ Lithium, mentioned only as being effective in prophylaxis against bipolar affective disorder, is effective in augmentation treatment for the one third of patients who do not respond to the first drug used ${ }^{3}$ and is also licensed for long term treatment of unipolar depression. ${ }^{+}$Further, there is evidence that overall mortality and suicide rates are decreased in patients with recurrent mood disorders who are treated with lithium compared with untreated patients. ${ }^{5}$

General practitioners (who see and treat 95\% of depressed patients) should be encouraged to consider a wider range of drugs than the older tricyclic agents for managing their depressed patients.

\section{Poisons Unit,}

London SE1 9RT

JOHN A HENRY

Department of Psychological Medicine,

St Bartholomew's Hospital,

London EC1A 7BE

1 Paykel ES, Priest RG. Recognition and management of depres sion in general practice: consensus statement. BMF 1992;30 1198-202. (14 November.)

2 Prescribing for unlicensed drugs or using drugs for unlicensed indications. Drug Ther Bull 1992;30:97-9.

3 Dinan TG, Barry SA. Comparison of electroconvulsive therapy and combined lithium tricyclic combination in depressed tricyclic non-responders. Acta Psychiatr Scand 1989;80: 97-100.

4 Coppen A, Abou-Saleh MT. Lithium in the prophylaxis of unipolar depression: a review. I $R$ Soc Med 1983;76:297-301.

5 Coppen A, Standish-Barry H, Bailey J, Houston G, Silcocks P, Hermon C. Does lithium reduce the mortality of recurrent mood disorders? I Affective Disord 1991;23:1-7.

\section{Informing patients about clinical trials}

EDITOR,-The public has many misconceptions about the nature and conduct of clinical trials, and this may contribute to the overall low level of participation in trials. Even after giving conventional informed consent patients often forget or misunderstand the basic elements of a particular study.' Explaining such difficult concepts as clinical uncertainty or randomisation to patients, some of whom may still be in a state of emotional shock after learning their diagnosis, remains a major communication challenge for health professionals. Kim A Priestley and colleagues highlight the poor readability of many consent forms for specific research protocols and the need for a simpler writing style.

Attention is now focused on improving the methods used to educate patients about clinical trials. We have recently developed a patient information booklet on clinical trials entitled Understanding Clinical Trials: Questions and Answers." This is available as an information resource for patients interested in taking part in a clinical trial and supplements the detailed information usually provided on a particular study. It describes the nature and purpose of clinical trials, their potential benefits and risks to patients, the main features of a properly designed trial, and suggested questions for the patient to ask the doctor about a particular trial.

The importance of piloting such a handout for patients among both colleagues and a sample of the target consumers was reinforced by Tony Smith." Pretesting of educational materials helps reduce the uncertainty of producing material that may be misunderstood. For our booklet we assessed factual accuracy, comprehension, and various attitudes towards its contents by testing its use on about 100 health professionals and patients before distribution. ${ }^{5}$ From the information gleaned substantial improvements have been made: the language has been simplified, the section on benefits and risks expanded, and illustrations and a page for patients' notes added.

We believe that such a booklet is a helpful adjuvant to individual discussion and for enlisting the cooperation of patients and their families in clinical trials. Exactly what information patients consider to be pertinent to their decision to accept or refuse entry to a trial remains unclear: different educational strategies will probably work for different groups of patients. A clinical trial is planned to evaluate this booklet's contribution to patients' comprehension, recruitment, and compliance in a national trial in cancer and AIDS.

HIV/AIDS Unit,

Westminster Hospital,

London

Cancer Research Campaign Clinical

PHILIPPA EASTERBROOK

Trials Centre,

London

1 Cassileth BR, Zupkis RV, Sutton-Smith K, March V. Informed consent-why are its goals imperfectly realized? $N$ Engl $\mathcal{F}$ Med consent-why are
1980;302:896-900.

2 Priestley KA, Campbell C, Valentine CB, Denison DM, Butler NP. Are patient consent forms for research protocols easy to NP. Are patient consent forms for research
read? $B M$ 1992;305:1263-4. (21 November.)

3 Easterbrooke PJ, Houghton J. Understanding clinical trials: questions and answers. London: Cancer Research Campaign Clinical Trials Centre, 1991

4 Smith T. Information for patients. BMF 1992;305:1242. (21 November.)

5 Easterbrook PJ, Houghton J. Towards more informed consent in clinical trials: evaluation of a patient information booklet. Pharmaceutical Medicine 1992;6:297-308.

\section{The health divide}

EDITOR,-Richard G Wilkinson's editorial reminds us that the widening of health inequalities in the United Kingdom is responsible for our declining position in the international health league.' The author emphasises that countries with smaller differences in health between socioeconomic groups also have lower overall mortality and that this is linked to narrower differences in income. While other governments, in line with the World Health Organisation's "health for all" strategy, ${ }^{2}$ are tackling socioeconomic disadvantage in health practically, this seems to be neglected in the white paper The Health of the Nation.

Shewry et al showed clearly that the more socially disadvantaged had more risk factors for coronary heart disease and suggested that health education and management resources should be targeted according to the socioeconomic profile of an area. ${ }^{4}$ It seems that the revised strategy for health promotion and management of chronic disease in general practice will ignore this and instead be based on capitation and list size. Thus many deprived populations will once again lose out and be marginalised.

Baker observed that patients in underprivileged areas were served by less developed practices 5 and suggested that family health services authorities and medical audit advisory groups should target their efforts towards supporting the development of these practices. The Association of Community Health Councils for England and Wales says that the move towards population based funding for health districts will see some inner city areas losing up to $24 \%$ of their budgets; it has called for regional health authorities to add a deprivation weighting when allocating money to districts. ${ }^{6}$

The message is clear: that accurate targeting of resources to deprived areas is essential to improve the health of the nation. ${ }^{7}$ The Jarman underprivileged area score is a move in the right direction, 